\title{
ANALISIS DAN PERANCANGAN SISTEM INFORMASI PENDAFTARAN PASIEN RAWAT JALAN DI RSUD KOTA BENGKULU
}

\author{
Sudirman, Subli, Alita Noviara \\ Akademi Kesehatan Sapta Bakti Bengkulu
}

\begin{abstract}
Tujuan dari perancangan sistem ini adalah untuk memberikan gambaran secara umum kepada pemakai dalam pembuatan rancangan sistem yang baru untuk mengembangkan sistem yang lama. Sehingga diharapkan sistem yang baru dapat membantu mengatasi kekurangan yang ada dan dapat menghasilkan informasi serta laporan yang cepat dan tepat di RSUd Kota Bengkulu. Adapun sistem yang diusulkan merupakan langkah untuk mengefektifkan dan mengefisiensikan sistem yang lama dengan menggunakan sistem yang baru. Instrument penelitian yang digunakan pada penelitian ini adalah dengan cara pengamatan (Observasi) data yang dikumpulkan dengan melihat secara langsung dari objek yang diteliti yaitu sistem pendaftaran pasien rawat jalan di RSUD Kota Bengkulu dan juga dengan pedoman wawancara data yang dikumpulkan dengan cara melakukan wawancara kepada bagian kepala rekam medis. hasil penelitian ini adalah membuat sebuah perancangan prosesdur yang dapat digunakan untuk mendukung proses sistem yang berjalan di RSUD Kota Bengkulu, dengan adanya konsep perancangan sistem pasien rawat jalan dapat mengembangkannya untuk kepentingan operasional rumah sakit dan dapat digunakan untuk sistem aplikasi yang berkaitan dengan data pendaftaran rawat jalan.
\end{abstract}

\section{PENDAHULUAN}

Untuk menigkatkan mutu pelayanan rumah sakit, dibutuhkan pengelolaan rekam medis yang baik salah satunya dengan menerapkan sistem komputerisasi dalam pengolahan data rekam medis. Rekam medis adalah berkas atau dokumen yang berisikan kumpulan data pasien yang memeriksakan diri di sebuah rumah sakit atau tempat pelayanan kesehatan. Rekam medis ini berisi biodata lengkap pasien, riwayat kesehatan pasien selama berobat di rumah sakit atau tempat pelayanan kesehatan tersebut. Sehingga dengan adanya rekam medis dapat memberikan informasi tentang riwayat kesehatan pasien.
RSUD Kota Bengkulu merupakan salah satu rumah sakit yang ada di Provinsi Bengkulu. Rumah Sakit Umum Daerah Kota Bengkulu Mulai Beroperasi pada bulan Januari Tahun 2014 dengan Izin Operasional Sementara Walikota Bengkulu Nomor 49 Tahun 2013 tertanggal 27 Februari tahun 2013 dan diregistrasi pada tanggal 28 februari tahun 2013 dengan kode Rumah Sakit 1771002S, pada bagian pendaftaran pasien rawat jalan, sistem pendaftaran masih dilakukan secara manual dimana data pasien dicatat dalam buku register dan sering terjadinya kesalahan dalam pencatatan serta sulitnya mencari informasi tentang data pasien.

Dalam visi pembangunan kesehatan kota Bengkulu adalah untuk mewujudkan 
pembangunan kesehatan yang berkualitas, terjangkau melalui pendekatan preventif, kuratif, dan rehabilitative. Oleh karena itu, dibutuhkan suatu sistem informasi untuk mengurangi terjadinya kesalahan dalam pelayanan pendaftaran pasien, melalui analisis dan perancangan sistem informasi pendaftaran pasien rawat jalan.

\section{LANDASAN TEORI}

\section{Pengertian Rekam Medis}

Menurut Permenkes Nomor 269/MENKES/PER/III/2008 rekam medis adalah berkas yang berisikan catatan dan dokumen tentang identitas pasien, pemeriksaan, pengobatan, tindakan dan pelayanan lain yang telah diberikan kepada pasien. Menurut Depkes Ri (2006) mengemukakan bahwa "Proses kegiatan penyelenggaraan rekam medis dimulai pada saat penerimaan pasien dirumah sakit, dilanjutkan dengan kegiatan pencatatan data medis oleh dokter atau dokter gigi atau tenaga kesehatan lainnya yang memberikan pelayanan langsung kepada pasien.

2. Pengertian Sistem Informasi Rumah Sakit

Menurut Ery Rustiyanto (2011, 36) Sistem Informasi Manajemen Rumah Sakit (SIM RS) yaitu suatu rangkaian kegiatan yang mencakup semua pelayanan kesehatan (rumah sakit) disemua tingkatan administrasi yang dapat memberikan informasi kepada pengelola untuk proses manajemen (berhubungan dengan pengumpulan data, pengolahan data, penyajian infornasi, dan analisa) pelayanan kesehatan di rumah sakit. peran sistem informasi didalam kegiatan manajemen rumah sakit sangatlah membantu dan mempunyai peran yang sangat efektif dalam proses pelayanan kesehatan dirumah sakit, dengan sistem informasi seorang pimpinan rumah sakit dapat mengambil suatu kebijakan secara cepat, tepat dan akurat berdasarkan informasi yang didapat dari pelayanan kesehatan dirumah sakit yang dipimpinnya.

\section{METODE}

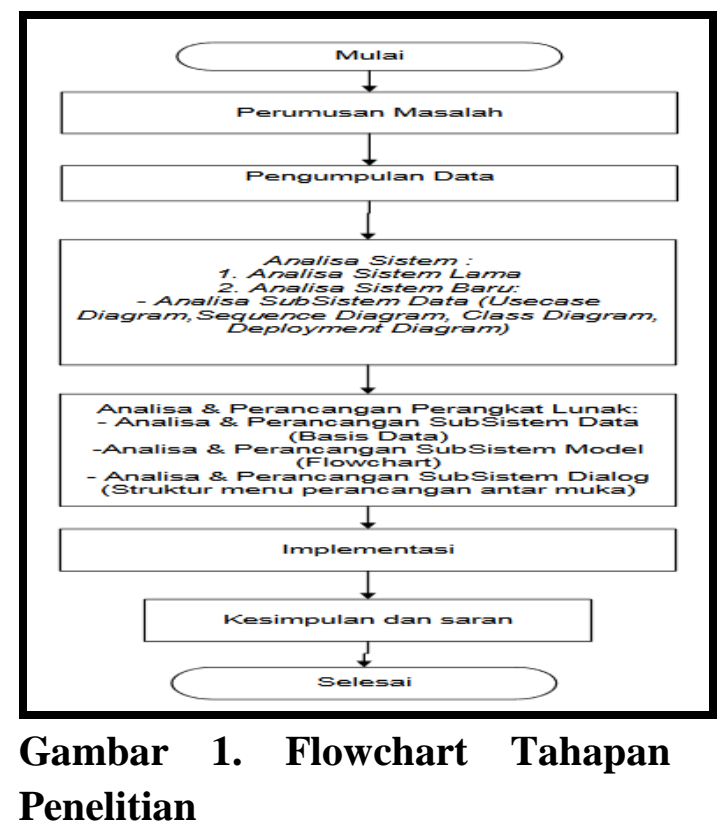

Data yang diambil merupakan data hasil wawancara dengan pihak rumah sakit serta data dari formulir pendaftaran rawat jalan di RSUD Kota Bengkulu. Cara pengumpulan data melalui studi kepustakaan, pengamatan, dan wawancara.

\section{HASIL DAN PEMBAHASAN}

\section{a. Analisis Sistem}

Alur sistem yang sedang berjalan pada sistem pendaftaran pasien rawat jalan pada RSUD Kota Bengkulu. 


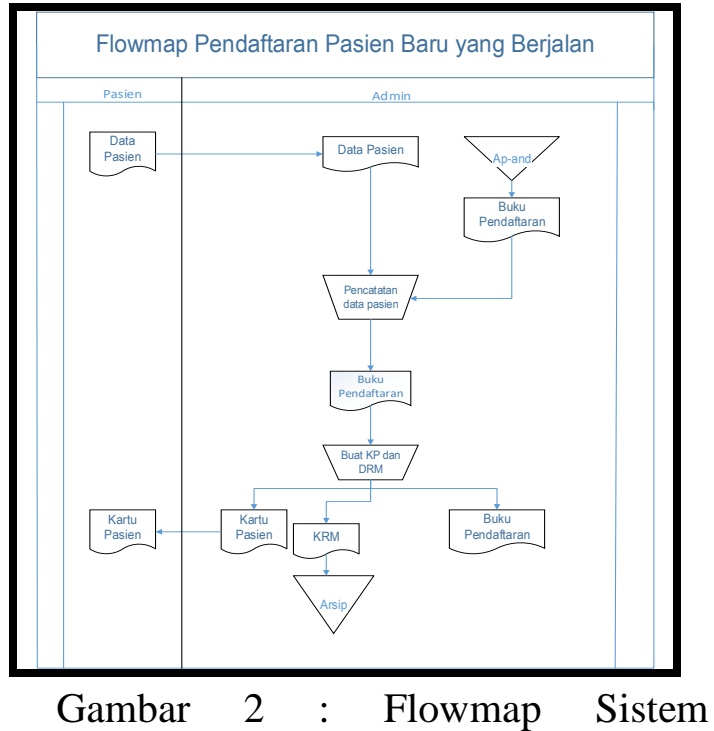

pendaftaran yang sedang berjalan

alur pendaftaran rawat jalan secara manual dimulai dengan pasien mendaftar di bagian tempat pendaftaran, pasien ditanya pernah berobat atau belum. Jika pernah berobat berarti pasien tersebut adalah pasien lama dan jika belum pernah berobat berarti pasien tersebut adalah pasien baru.

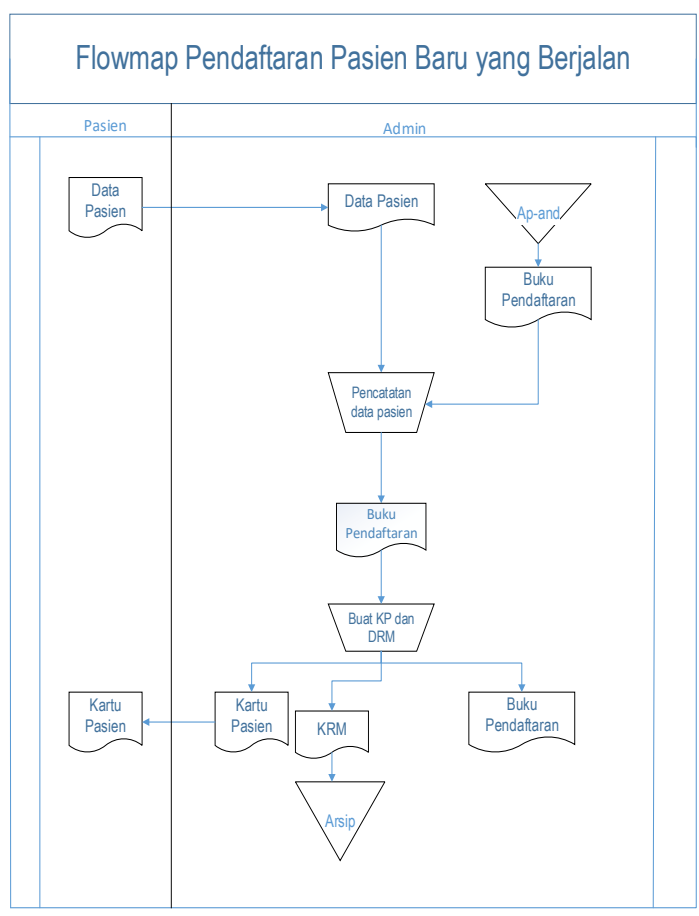

Gambar 3. Flowmap Pendaftaran Pasien baru yang berjalan.

Sistem pendaftaran pasien yang sedang berjalan masih secara manual, artinya registrasi data pasien tersebut disimpan disuatu buku register untuk selanjutnya diarsipkan yang media penyimpanannya kurang efektif karena tidak adanya sistem database di RSUD Kota Bengkulu.

Saat pasien datang ke rumah sakit, bagi pasien rawat jalan langkah pertama yang harus dilakukan adalah menuju bagian administrasi pendaftaran. Jika pasien tersebut adalah pasien lama (sudah pernah berobat) sebelumnya di rumah sakit,maka pasien tersebut didaftarkan ke poliklinik yang akan ditujunya dan bagianMedical Record akan mencari file status atau daftar ringkasan berobat pasien tersebut. Apabila pasien tersebut baru pertama kali berobat ke rumah sakit, maka pasien diharuskan mengisi biodata pada formulir yang telah tersedia, dan petugas pendaftaran membuatkan kartu berobat bagi pasien.

Untuk perancangan system pendaftaran yang akan dibangun, maka terlebih dahulu penulis akan menjelaskan perancangan prosedur yang diusulkan, diantaranya adalah sebagai berikut : Pasien menyerahkan data pasien kebagian admin, bagian admin menginputkan data pasien ke dalam database, Admin mencetak kartu pasien dan menyerahkan kembali ke pasien sedangkan Prosedur pendaftaran Pasien lama yang diusulkan : Pasien menyerahkan kartu pasien ke bagian admin, bagian admin mencari dan menginputkan no rekam medis pasiendan mencari status pasien, Admin menyerahkan Berkas rekam medis ke poli klinik untuk diperikasi oleh dokter, Untuk rekap laporan bagian admin 
mencetak rekap kuunjungan pasien dan diserahkan ke pimpinan.

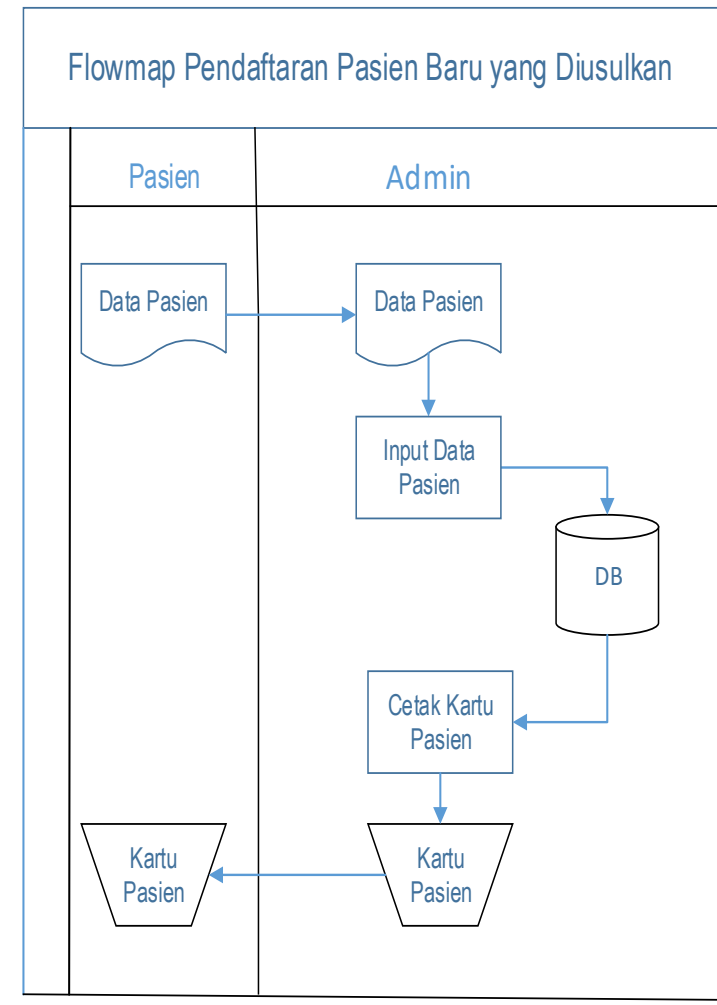

Gambar 3. Flowmap Pendaftaran Pasien baru yang di usulkan

\section{DIGRAM KONTEKS DAN DAD}

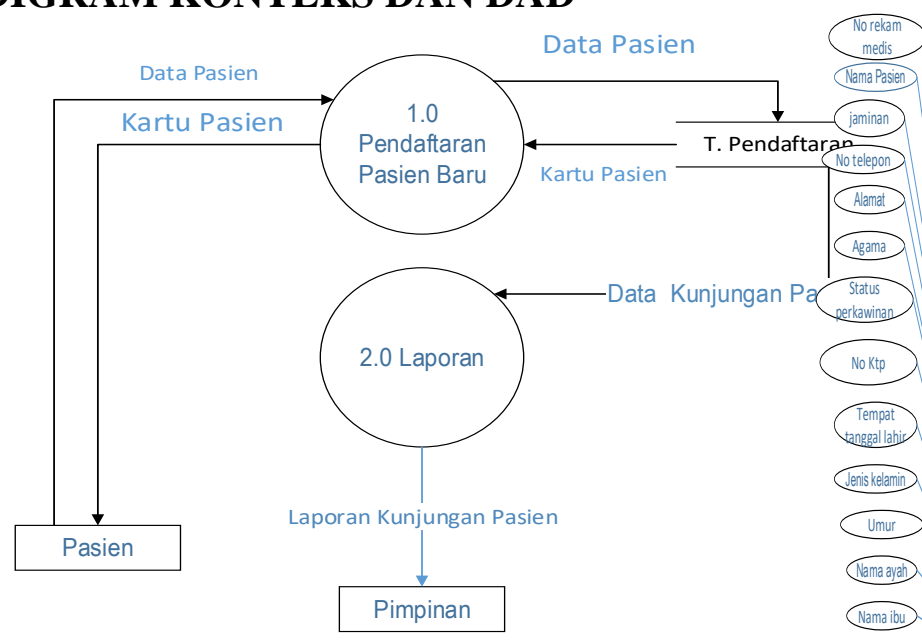

Gambar 4 Data Flow Diagram level 2

Dari DFD ( Data Flow Diagram) level 1 yang prosesnya masih bersifat umum, maka dijelaskan kembali dengan adanya DFD level 1 ,sebagai berikut :
DFD Level 2 dari Proses 1.0 sistem yang diusulkan :

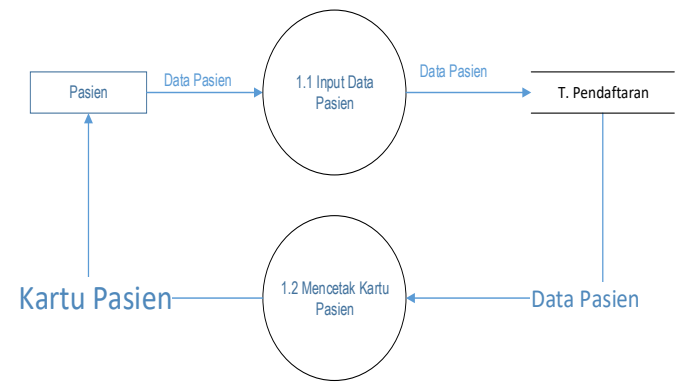

Entity Relationship Diagram merupakan suatu diagram yang menjelaskan hubungan antar data dalam basis data berdasarkan suatu persepesi data yang terdiri dari objekobjek dasar yang mempunyai hubungan atau relasi satu sama lain. Penggambaran ERD (entity relationship Diagram) akan membantu perancang sistem dalam melakukan perancangan proses yang kelak akan dituangkan dalam bentuk barisbaris program.

Entity Relationship Diagram (ERD) yang diusulkan dalam perancangan Sistem Informasi Pendaftaran Rawat Jalan di RSUD Kota Bengkulu sebagai berikut : 
RSUD Kota Bengkulu dilakukan, maka penulis dapat mengambil kesimpulan sebagai berikut.

1. Sistem pendaftaran pasien rawat jalan sistem yang digunakan di RSUD Kota Bengkulu masih menggunakan sistem secara manual.

2. Perancangan sistem informasi pendaftaran pasien rawat jalan di RSUD Kota Bengkulu yang semula masih manual dikembangkan menjadi pendaftaran berbasis komputer yang terintegrasi dari berbagai unit di RSUD Kota Bengkulu.

3. Upaya-upaya dalam meminimalisir data pasien rawat jalan yang disebabkan oleh faktor SDM masih manual, sarana dan prasarana terbatas sehingga perlu dilakukan sistem dari manual ke komputerisasi sekaligus meningkatkan kemampuan SDM serta melengkapi sarana dan prasarana yang diperlukan.

\section{DAFTAR PUSTAKA}

Abdul Kadir. (2003). Pengertian Database. Yogyakarta: Abdul Kadir.

Abdul Kadir. (2014). Pengenalan Sistem Informasi. Yogyakarta: Abdul Kadir.

Departemen Kesehatan RI. (2002). Teknologi Sistem Informasi Rumah Sakit. (diakses 10 Mei 2017), diunduh dari http://scholar.google.co.id.

Hall. (2001). Pengertian Sistem Informasi. Yogyakarta: Andi.

Iswahyudi, Vivi Sahfitri Susan Dian Purnamasari. (2013). Analisis dan Perancangan Basis Data Pasien rawat Jalan Pada Rumah Sakit Uum Daerah Dr.IBNU SUTOYO
BATURAJA. (diakses $11 \mathrm{Mei}$

2017), diunduh dari

http://scholar.google.co.id.

Jogiyanto. (2005). Konsep Dasar Sistem

Informasi. Yogyakarta: Andi.

Khusnul Khotimah, Dadang Sudrajat, Raditya Danar Dana. (2013).

Analisis Perancangan Sistem

Informasi Database Rekam Medis

Rumah Sakit Umum Daerah Kota

Bengkulu. (diakses 10 Mei 2017), diunduh dari

http://scholar.google.co.id.

Menurut ermenkes No.

269/MENKES/PER/III/2008.(2013)

.Pengertian Rekam Meds. (diakses

10 Mei 2017), diunduh dari

http://scholar.google.co.id.

Sintha Setyaningrum. (2013). Konsep dan Perancangan Basis Data.Yogyakarta. Wildan dan Hidayat. (2008). Pengertian Rawat Jalan. Yogyakarta (diakses 10 Mei 2017), diunduh dari http:/www.google.co.id. 